\title{
Jews and politics in Hungary in the Dualist era, 1867-1914
}

\author{
Miklós Konrád*
}

\author{
Institute of History, Hungarian Academy of Sciences, Budapest, Hungary
}

\begin{abstract}
To what extent can one speak of "Jewish politics" in Hungary in the Dualist era? With emancipation in 1867 , Hungarian Jewry officially ceased to exist as a legally and politically separate body. Naturally, at least one specific political interest still bound together Hungary's Jews; they all shared the common desire not to suffer on account of their being Jewish. Beyond that, however, Hungarian Jewry was not a politically undivided group. In terms of its relationship to Jewish tradition, levels of acculturation and socioeconomic status, the Jewish population, which had already been far from homogeneous before 1867, underwent a far-reaching polarisation in subsequent decades. Furthermore, since Judaism was officially defined on a purely denominational basis, Jews were theoretically non-existent on any level other than the strictly religious. Consequently, they could not fight for any specific political, social or economic interest. Nevertheless, from Orthodox Jewry to upper and middle-class Jews, each group in its own way fought for specific interests, according to its own well-understood needs. This paper examines how the different sub-groups of Hungarian Jewry strove - rather successfully - for the defence of their particular group interests.
\end{abstract}

Keywords: Hungarian Jewry; Jewish politics; Hungarian politics; Jewish representation; Orthodox Jewry; Shtadlanut; Hungarian-Jewish economic elite; Jewish middle class; Hungarian anti-Semitism

Among the specific features in the history of Hungarian Jewry after emancipation in 1867 , one of the most salient is the attitude of the country's traditional political and social elite towards the Jews. Nowhere else in contemporary Europe was the elite so much in need of the Jewish population. On the one hand, Jews played a decisive role in the economic modernisation of the country. ${ }^{1}$ On the other, Hungary's traditional political elite, who lived under the spell of a homogeneous nation-state, was well aware that the increase in "Hungarians" (that is, those who declared Hungarian to be their mother tongue at the population census) to $51.4 \%$ of the total population by 1900 was due in large part to the Jewish linguistic acculturation. ${ }^{2}$ In the Hungary that regained a large measure of its independence in 1867 and impetuously embarked on the path of modernisation, the Jews were indispensable to the traditional Hungarian ruling classes. Regardless of the feelings that individual politicians harboured toward Jews, Hungarian state nationalism in the Dualist era could not be anti-Semitic.

Politically speaking, this had three major consequences. In the first place, throughout the half-century of Dualism, state power remained, on the whole, well-disposed toward the Jews. In 1882-3, at the time of the Tiszaeszlár blood libel affair, the political authorities took firm - though belated - steps against the overt manifestations of antiSemitism. ${ }^{3}$ In the early 1900 s, the somewhat anti-Semitic agrarian movement gained

*Email: konradm@t-online.hu 
influence in the two major political parties, the Party of Independence, which opposed the Austro-Hungarian Compromise of 1867, and the Liberal Party, which supported the Compromise and remained in power during the half-century of Dualism, with the exception of the years 1906-9. ${ }^{4}$ The agrarians had a strong influence on the so-called Coalition government that held power during these three years; but when the Liberal Party returned to power in 1910, under the name National Labour Party, the agrarians lost much of their influence and its so-called "mercantile" wing was by far the strongest one. Beyond these fluctuations, and even if a growing part of the nobility, the traditional Magyar political elite, increasingly resented the growing power of the Jews, the official position remained unchanged; the role played by the Jews in national life was repeatedly declared to be beneficial to Hungary. From Kálmán Tisza, Prime Minister between 1875 and 1890, to his son István Tisza, Prime Minister between 1904 and 1905, and then from 1913 to 1917 , the political authorities consistently condemned anti-Semitism. ${ }^{5}$ When asked in 1910 about his feelings toward Jews, the newly appointed Prime Minister Károly Khuen-Héderváry categorically refused to answer, since, as he explained, "the sheer question implies the possibility that someone holding a governing office may be prejudiced against any denomination." "I am proud" - he declared a year later - "that Hungarian liberalism has never allowed anti-Semitism to gain ground. As far as I am concerned, I will always follow that liberal line."

In the second place, the government's policy explains why in Hungary - in contrast to Austria or Germany - Jews did not establish any organisation with the declared aim of fighting anti-Semitism, or one that represented any specific Jewish political interest. In an age of homogenising nationalism that theoretically condemned all forms of Jewish particularism, other than the strictly religious one, in a context where the opposition of "Jewish" versus "Hungarian" interests were voiced by the anti-Semites, it was understandably not in the Jewish interest to appear as a corpus separatum in political life. In the Hungary of the Dualist era, the political situation allowed them to avoid taking such a route.

The third consequence once again contrasted to the situation of the Jews in Germany, which witnessed "the virtual exclusion of Jews, including members of the elite, from active participation in public life" in the final quarter of the nineteenth century. ${ }^{8}$ In Hungary, Jewish political power took a slow, but upward trend. The importance of the Jewish population, which grew from half a million at the time of the emancipation in 1867 , to more than 900,000 , or $5 \%$ of the total population in 1910 , ensured that Jews had significant political influence. This was all the more so since censitary suffrage advantaged Jews who were better off than their non-Jewish fellowcitizens and were thus over-represented among the voters. Andrew C. Janos estimated that Budapest's Jewish inhabitants $(203,687$ persons, or $23.1 \%$ of the total population in 1910) represented $50 \%$ of the city's voters. ${ }^{9}$ This estimate is overstated, but there is no doubt that an anti-Semitic candidate did not have the slightest chance of being elected in Budapest in a local or a general election. However, that was not all. It cannot be proven that the increasing number of Jewish MPs during this period, which incidentally reveals the readiness of non-Jews to vote for Jewish candidates, was a direct result of the growing weight of Jewish voters. ${ }^{10}$ This increase also stemmed from the policy of the traditional elite, who, even if reluctantly, slowly began to share part of its political power with Jewish politicians. With the appointment between 1910 and 1917 of five converted and one unconverted Jewish government ministers, ${ }^{11}$ the last decade of the Dualist era witnessed the appearance of the Jews at the highest level in the Hungarian state. 
To what extent can one speak of Jewish politics in the Dualist era? With emancipation, which gave equal rights to Jews as Hungarians of the Jewish religion, Hungarian Jewry officially ceased to exist as a politically separate body. Naturally, specific interests still bound Hungary's Jews together. The most obvious of these was that they all shared a common desire not to suffer grievances on account of being Jewish. Politically speaking, this meant that they were, as everywhere else, staunch supporters of political liberalism. Beyond that, however, Hungarian Jewry was not a politically undivided group. In terms of their relationship to Jewish religious tradition, their level of acculturation, their socioeconomic status, Hungarian Jewry, which was far from homogeneous before 1867, underwent a far-reaching polarisation in subsequent decades. From the partly converted 28 Jewish barons, to the ultra-Orthodox masses in the north-eastern part of the country, Hungary's Jews were not a uniform group, and thus, did not have uniform political interests.

\section{Orthodox Jewry}

As a result of their incapacity to agree at the Jewish Congress of 1868-9 on a common organisation of Jewish communities, Hungarian Jewry split into two institutionally separate bodies - Neolog (Reform) and Orthodox. ${ }^{12}$ Both had its statutes officially recognised by the Hungarian state. ${ }^{13}$ Hungarian Jewish orthodoxy represented a unique feature in the history of modern European Jewry. Among those countries where Jews had been emancipated, Hungary was the only one (would-be) nation-state where about half of the Jewish population strictly adhered to - a somewhat reinvented - Jewish religious tradition and embarked only reluctantly, or did not embark at all, on the path of linguistic and cultural acculturation. ${ }^{14}$ Even in 1900, sermons were delivered in Hungarian in only $11 \%$ of Orthodox synagogues, as against $69 \%$ in German, and $20 \%$ for Yiddish. ${ }^{15}$ The Orthodox camp, who rejected integration into Hungarian society and whose ultra-Orthodox wing was hostile to even the most basic forms of acculturation, formed a separate entity in terms of its political interests. ${ }^{16}$

However, Orthodox Jewry was not a homogeneous bloc either. The Hasidic Jew living in a village in the north-eastern part of the country who sent his son to Yeshiva, and the petty shopkeeper of a Transdanubian town who managed to send his children to Realschule, did not share the same approach to politics. Ultra-orthodox Jews were interested in Hungarian politics only inasmuch as government policy affected their traditional way of life. They were certainly indifferent to the major political issues of the day, such as support of or opposition to the Austro-Hungarian Compromise. In contrast, the somewhat acculturated Orthodox Jews had already entered the ideological sphere of Hungarian politics; they were committed either to the Liberal Party or to the Party of Independence, or, like many of their non-Jewish fellow-citizens, sympathised with the Party of Independence while supporting the Liberal Party.

What did Orthodox Jews want? The mass of Orthodox Jews, most of whom were petty traders, shop and innkeepers, remained politically silent. Their interests were represented at national level by the official representation body of the Orthodox congregations, the Orthodox Israelite Mediation Committee, called the Orthodox Israelite Central Office after 1906 (hereafter, Orthodox Office). In principle, the Orthodox Office, just like its Neolog counterpart, the National Office of Israelites, only acted as a mediator between the authorities and the Jewish communities. In practice, both gradually became the central representative bodies of Orthodox and Neolog Jewries. ${ }^{17}$ As the Orthodox Office stated on numerous occasions, Orthodox 
Jews merely wanted the authorities to respect the statutes that guaranteed their way of life and to protect them from the intrigues of the Neolog leadership, whom the Orthodox Office suspected, not altogether wrongly, of striving for the reunification of Hungarian Jews in order to compel Orthodox Jewry to take the path of religious and cultural modernisation.

What did the Central Orthodox Office offer in return? First, it committed to the "ideal of the Hungarian state," that is, loyalty to the Hungarian state as against the nationalities. Second, it gave unfailing political support for the government in power. Indeed, its official press praised one administration after another. If necessary, the president of the Orthodox Office personally intervened at local level to ensure that Orthodox voters would support the government party candidate at elections. It is quite telling that the orthodox leadership thought that they would strengthen their alliance with the governing political elite by repeatedly stressing that, in contrast to the "pushy" Neologs, the socially humble Orthodox Jews did not represent any threat to the traditional Hungarian elite's economical and political position. ${ }^{18}$ Indeed, among the 60 unconverted Jews elected to Parliament between 1867 and 1918, none was Orthodox, and only two of the 346 Jews who were raised to the nobility by 1918 were Orthodox at the time of their ennoblement. ${ }^{19}$

However, this strategy did not mean that Orthodox Jews, or at least the Orthodox Office and leading Orthodox rabbis, were politically passive. State recognition of Orthodox Jewry's own statutes, that is, of their organisational separation from the Neologs, was precisely the result of the Orthodox leadership's political activism. In its battle against Neolog Jews, the Orthodox Office remained quite combative even after 1871. By petitioning the Hungarian Parliament, it succeeded in delaying by years the setting up of the Rabbinical Seminary, which finally opened its doors in Budapest in $1877 .{ }^{20}$ At the turn of the century, the Orthodox Office's Hungarian language newspapers had practically no other aim than to denounce the alleged machinations of the Neolog Jews. ${ }^{21}$

As to the Orthodox leadership's relationship to the state, whenever it perceived a threat to its religious life, it did not hesitate to oppose the authorities. The Orthodox Office vehemently fought all government attempts to rescind the right guaranteed to Orthodox congregations in 1877 to set up heders and to deliver their religious instruction without state control. ${ }^{22}$ For years, it lobbied the Ministry of Religious Affairs of successive governments for Jewish elementary and high school students to be exempted from writing and drawing on Saturdays - a concession finally granted in 1893. At the beginning of the 1890s, the Orthodox Office also fought against the compulsory Sunday rest law, trying to obtain special derogation for Orthodox Jews. ${ }^{23}$

Besides the Orthodox leadership, ordinary Orthodox Jews would also occasionally demonstrate their readiness to defend their interests. In 1913, Parliament debated a bill which stipulated that all shops should close on Saturdays at 6 p.m. Through intense lobbying, the Orthodox shopkeepers and innkeepers, who used to open on Saturdays after the end of the Shabbat, secured an amendment to the parliamentary bill. The modified version allowed them to keep their business open practically as late as they wanted to. ${ }^{24}$

In the case of the Sunday rest law, the Orthodox Office's efforts ultimately proved vain; but more than once, its actions were successful. In fact, and this is an indication of how far the government was ready to go to secure Orthodox Jews' support, the Orthodox Office was able, on several occasions, to convince the government to modify or even repeal ministerial decrees. In 1900, the Interior Ministry revoked a 
decree it had passed a year earlier that prohibited the traditional manner of disinfecting the circumcised penis of newborn boys. ${ }^{25}$ On two occasions, in 1888 , then again in 1904, the Minister of Religious Affairs restricted the elected Orthodox courts' exclusive rights to conflict resolution within Orthodox communities. To the objection of the Orthodox Office, however, the Ministry gave way on both occasions, issuing decrees in 1890 and 1905 that reinstated the Orthodox courts' original sphere of competence. ${ }^{26}$

The administration even tolerated the fact that Orthodox Jews refused to abide by some laws and decrees. In spite of the compulsory school attendance law, many ultraorthodox Jews of the north-eastern counties preferred to send their children to illegal Jewish primary schools, that is heders, which, in contrast with the legally recognised ones, also taught some secular subjects. ${ }^{27}$ Although county education supervisors would occasionally close some of these schools, they clearly never made real efforts to do away with them. And last, but not least, despite a decree of 1884 stating that rabbis had to be Hungarian citizens, and although the so-called "reception" law of 1895 specified that rabbinical education must take place in Hungary - two conditions which a number of Orthodox rabbis did not satisfy - the political authorities did nothing to enforce these regulations. ${ }^{28}$

It is thus quite clear that the Orthodox Office's policy of backing successive governments was rewarded in return; but this strategy also had its limits. The limit was not the one the Orthodox Office theoretically imposed on itself; that is, the sole defence of the Orthodox religious way of life, since the Orthodox leadership did more than merely protect its own group. At the time of the Tiszaeszlár affair, the orthodox leadership went publicly against anti-Semitism, requesting European Christian scholars to attest to the groundless nature of the blood libel. ${ }^{29}$ From the $1890 \mathrm{~s}$, the Orthodox Office did not hesitate repeatedly to request from the government an increase in the legal financial support given by the state to the Jewish denomination. ${ }^{30}$

The Orthodox leadership's room for manoeuvre was essentially limited by its policy of loyalty to those in power. Apart from religious matters, where the Orthodox leadership was quite combative, it allowed no room for political opposition. In 1895, the Hungarian Parliament enacted the "reception" law, which raised the "Israelite denomination" to equal status with Catholic and Protestant churches. The "reception" bill was initially opposed by the Orthodox leadership, but only as long as the government position seemed uncertain. As soon as the government declared its support for the bill, the Orthodox leadership expressed its support for the legislation too. ${ }^{31}$ Although the Orthodox press inveighed in the 1900s against the consumer cooperatives established by the agrarian movement that were detrimental to the interests of retailers, it avoided criticising political authorities supporting the cooperatives. In a similar way, while it kept railing against the border police, established in 1906, who regularly returned to Galicia Jewish families that had been settled in Hungary for decades, it never failed to emphasise that "high governmental circles are totally innocent of the excesses of their mean-spirited subordinates." ${ }^{\prime 32}$

Nevertheless, Orthodox Jewry's policy was successful in its fundamental aims. Successive governments respected the Orthodox Statutes, even confirming these without further ado in $1906 .{ }^{33}$ It should be stressed that by doing this, the political elite guaranteed Orthodox Jews a way of life that de facto prevented primary identification with the Hungarian nation. Hungarian Jews were certainly required to "assimilate" to the Hungarian nation, but besides the fact that no one ever explained what exactly this meant, in practice, this requirement concerned only Jews who entered the middle classes. 
The political behaviour of the Orthodox Office was a mixture of the traditional shtadlanut politics of personal intercession on behalf of the corporate community and the modern use of political lobbying. The very birth of the Orthodox organisation, the recognition by the government of its right to set up its own representative body, resulted from the Orthodox leadership's ability to go beyond shtadlanut politics, its understanding of the new political conditions and the pressure it could exert on the government by appealing to public opinion. In order to preserve its traditional way of life, the Orthodox leadership turned to modern political methods. Its policy of backing every government restricted its room for manoeuvre, but it stemmed from its wellunderstood interests and made it possible for the Orthodox Office to actively and successfully influence decision-making.

\section{The Jewish MPs}

"In this country," declared the Jewish MP Gyula Rosenberg in Parliament in 1898, "the Jew is nothing else, cannot be anything else, must not be anything else but a Hungarian of Jewish religion." 34 Although Judaism's Reform Movement in Hungary was much more moderate than in Germany, its basic principles were identical; the denationalisation of the Jews and the confessionalisation of Judaism constituted the foundation of the Neolog ideology of Jewish assimilation. Whether or not the Hungarian Jewish bourgeoisie believed in it, is questionable - more than often, it did not. However, one thing is certain. Regardless of the various ways they individually related to their own Jewishness, members of the Jewish upper and middle classes mutatis mutandis the Neolog Jews - were "assimilationists" in the sense that in political life, in accordance with the official doctrine, they did not want to appear as "Jews," but rather as "Hungarians of the Jewish persuasion." This was not a matter of external pressure. Their Jewishness inevitably influenced their political behaviour, but certainly less so than their socioeconomic status. As Jews, their political interest was precisely not to be considered as such. Neolog Jews adhered to the fiction of confessionalised Judaism because it was an irresistible rhetorical tool against anti-Semitism - even though it was an obviously inefficient one. If one was a Jew only by religion, being a Hungarian in every other aspect of life, there was no sense in talking about Jews in the political, economic or social life. The accusations directed against Jews were by definition null and void, since their object simply did not exist.

This ideological framework left little room for the expression of specific Jewish interests. Since Judaism was officially defined on a purely denominational basis, "Israelites" were theoretically non-existent on any level other than the strictly religious one. Consequently they could not have - and thus could neither represent nor fight for - any Jewish political, social or economic interest. In parliamentary politics, this meant that there could be no "Jewish MPs," but only Hungarians elected by other Hungarians. One should stress that this was also the case for MPs of other denominations. At least until the turn of the twentieth century, Hungarian politics denied the legitimacy of any group of interests to be represented as such in the Parliament. The members of the Lower House were considered as representing the whole nation. ${ }^{35}$ As the speaker of the Lower House, Tamás Péchy, declared in 1891, talking about Catholics: "I shall never admit under any circumstances that a member of the Hungarian Parliament votes according to his religion." 36

However, non-Jewish society was not always as dismissive of the obvious existence of specific Jewish interests, such as, for instance, having "their own" MPs. 
Beyond the desire to "give body" to the emancipation law, it was the importance of the Jewish population in the Fifth District of Budapest, the stronghold of the Jewish upper class, that in 1869 prompted a group of non-Jewish voters in the district to ask the Jewish private banker Mór Wahrmann to run for the elections. ${ }^{37}$ Mór Wahrmann became the first Jewish MP of the Hungarian Parliament and was re-elected in the district until his death in 1892 . When, in 1875 , during a parliamentary debate on a commercial treaty with Romania, Wahrmann began his speech by saying "as the honoured house knows, I myself am a Jew, and so I too have an interest in this matter," the members of Parliament responded with an "ovation." "38

This does not mean that it was not a delicate thing for a Jewish MP to stand up for Jewish interests. It is quite telling that Jewish MPs who spoke up for Jewish interests in Parliament rarely failed to stress that their only motivation was the defence of the general principle of equality before the law. Most Jewish MPs avoided speaking in Parliament on matters concerning the Jews. During the debate in 1880 on a memorandum sent to the Parliament by the Orthodox Office, there was not a single Jewish MP among the 21 speakers. Three years later, there were only two unconverted and one converted Jews among the 27 MPs reacting to the bill on Christian-Jewish marriages. ${ }^{39}$ Jewish MPs were also cautious in reacting against anti-Semitism. It took seven years before a Jewish MP finally objected to the anti-Semitic rants of Gyözö Istóczy, the leader of the Anti-Semitic Party, founded in 1883 in the aftermath of the Tiszaeszlár blood libel affair, and whose first speech against the Jews in 1875 marked the beginning of modern political anti-Semitism in Hungary. ${ }^{40}$ Jewish MPs preferred to delegate the role of defenders of the Jews to gentile MPs, who regularly condemned anti-Semitism; regularly, but not always. As a result of the Jewish MPs' reluctance to address the issue, on more than one occasion, no MP responded to the anti-Semitic rants delivered in Parliament.

When Jewish MPs condemned anti-Semitism, they did so on the grounds of public interest. By trying to exclude Jews from the Hungarian nation, anti-Semitism, they argued, weakened an already weak Hungarian nation besieged by its "internal enemies;" that is, the nationalities. Thus, anti-Semitism was contrary to the interests of the Hungarian nation. ${ }^{41}$ Of course, the tactical aim was to defend against accusations of particularism; but there could be no better argument in strategic terms either, since the authorities shared the very same view. As Minister of Agriculture Ignác Darányi, a politician otherwise close to the agrarians, stated in 1900: "It is an unpatriotic thing to divide and break up on religious lines a nation that is few in number, because those wishing to do so, shake the very foundations of the Hungarian state." 42

At any rate, out of the 60 unconverted Jewish MPs elected to Parliament during the Dualist era, just a few reacted repeatedly against anti-Semitism, or on any matter related to Jews. But one should note that many Jewish MPs did not speak much on any subject whatsoever. In contrast, those raising their voice in defence of the Jews were in all cases politicians who played an important role on the political scene. One should also note that if it was certainly a delicate thing to do, there is no indication that any of those who did so suffered any political disadvantage as a result.

\section{The Jewish upper class}

The large majority of the Jewish bourgeoisie supported the Liberal party, which, as aforementioned, held power during most of the Dualist era. While there is no statistical data to bear this out, their support of the governing Liberal Party has been put 
forward so often by contemporaries on all sides of the political spectrum as to be beyond dispute. ${ }^{43}$ Contemporary observers, especially progressive intellectuals and social democrat leaders (among whom many were also Jews), tended to interpret this loyalty as the continuation of an "inherited" political tradition, an inability to depart from an instinctively submissive attitude toward the state. ${ }^{44}$ Things were actually simpler than that. Upper and middle-class Jews predominantly supported the Liberal party because their interests drove them to do so, both as Jews and as citizens mainly engaged in commercial and service sectors and in free professions.

In the 1880s, during the years of the Tiszaeszlár blood libel affair, as well as at the time of the resurgence of anti-Semitism at the turn of the century, the Liberal party was always less tempted by anti-Semitism than the Party of Independence. The central point of the Liberal Party's political programme, the backing of the Austro-Hungarian Compromise, made it more appealing to the Jewish bourgeoisie, which, as elsewhere in Austria-Hungary, was a natural supporter of the monarchy. Moreover, the Liberal Party was always closer to business circles than the Party of Independence. Even if the agrarians gained influence within the Liberal party at the beginning of the 1900s, on the whole, it always supported liberal economic policies.

Sheer pragmatism also prompted the great majority of the Jewish bourgeoisie to vote for the Liberal Party. Since it rejected the constitutional arrangement of 1867, the Party of Independence was outside the system. Despite parliamentarianism, there could be in reality no change in power. The Party of Independence was quite aware of this; it is no accident that between 1875 and 1905, it did not even present enough candidates at the general elections to be able to win a majority in the Parliament. ${ }^{45}$ In 1905 , the only time in the period of Dualism when the Party of Independence won the elections, the coalition formed with its participation could achieve power only after it promised Emperor Francis Joseph not to contest the constitutional arrangement between Hungary and Austria; that is, only after the Party of Independence gave up the fundamental tenets of its programme.

Naturally, the Jewish bourgeoisie was not a homogeneous bloc. We do not have to be Marxists to admit that the political interests of the Jewish haute bourgeoisie were not identical to those of the middle-class masses.

If support of the governing Liberal Party prevailed among Jewish middle classes, among the upper classes it was almost unconditional. Since at the time of the economic modernisation that followed the Compromise of 1867 , the state was the largest business actor, a good relationship with the government in power was of crucial interest to the upper class. Beyond this imperative, however, the interests of the Jewish upper class coincided largely with those of the Liberal Party. In part for different reasons, both the Liberal Party and the Jewish upper class had a vital interest in upholding the terms of the Austro-Hungarian Compromise, and to keep unchanged the system of government established in 1867. Both wished to prevent the nationalities, the Hungarian peasantry, most of which was opposed to the Compromise, and the social democrat workers, who opposed the system en bloc, from taking part in the political decision-making process. When changes to the restricted suffrage were being considered, the position of the Jewish upper class was more generous. Nevertheless, throughout the Dualist era, it rejected the introduction of universal suffrage, as did the traditional governing elite.

Until the mid-1890s, the Jewish upper class enjoyed the full support of the government authorities. Few members of the traditional elite engaged personally in trade and industry, but successive governments and the state administration did everything to 
facilitate the economic activities of the emerging bourgeoisie. Political anti-Semitism, which emerged in the mid-1870s and culminated with the Tiszaeszlár blood libel affair in the early 1880 s, did not threaten the interests of the Jewish upper class. As a group, it did not react. It had actually no need to do so. Despite the vehemence of the anti-Semitic outburst, political anti-Semitism was at that time bound to fail. There could be no doubt as to the final response of the traditional elite. Indeed, though after a substantial delay, the authorities did finally take firm action against anti-Semitism, which, by the late 1880 s, almost disappeared from Hungarian political life.

From the mid-1890s, however, the support of the government was not so clearcut. State support for the agrarian-backed cooperatives, the Law of Incompatibility of 1901, and the anti-mercantile policies of the coalition government created a new situation. ${ }^{46}$

By this time the situation of the Jewish upper class had also changed: it had become the ruling class in an economic sense. At the turn of the century, the Jewish upper class controlled some $90 \%$ of Hungary's modern banking system and industrial plants. ${ }^{47}$ Like all modern economic elites in the post-industrial revolution era, it now tried to convert its economic influence into political power. It goes without saying that upper-class Jews did not strive for greater political influence as Jews (a number of them were in fact converted), but as members of an upper class composed predominantly but not exclusively of Jews. It is also clear that the upper class's political aspirations aroused such resistance because it was mainly composed of Jews. In effect this was what led the agrarian camp to mobilise itself, as it sought to preserve or increase the political weight of large landowners, and, more generally, of the traditional elite.

Thus, the so-called "agrarian-mercantile" antagonism between the traditional landowning class and the Jewish haute bourgeoisie was in fact an internal power conflict within the dominant classes. The Jewish upper class fought the agrarian camp by means of the National Association of Hungarian Industrialists. Founded in 1902, this body was not a Jewish organisation, even though it was dominated by the Jewish industrial and financial elite. Some $60 \%$ of the founding members were Jews or converted Jews. In 1910, it exercised all its financial and political influence to remove the agrarian-backed coalition government from power and to reinstate the Liberal Party, now called National Labour Party, as the governing party. ${ }^{48}$

This party, which governed the country until the end of the Dualist era, included both the large landowners and the Jewish upper class. Although the fight between "agrarians" and "mercantiles" did not end completely, the two camps nevertheless realised that they had more to lose than to gain from breaking off their political alliance. Their common interests dictated that they compromise. The Jewish upper class remained open to progressive ideas on the cultural level, but gave up the ambition it had displayed in the beginning of the 1900s to work on a reformulation of liberalism, because democracy no longer meant for the Jewish upper class the guarantee of the emancipation but rather, the danger of revolution and of the collapse of the AustroHungarian Empire. ${ }^{49}$

Through this compromise, the Jewish elite achieved its goal; it acquired a share in government power. Its role in the country's preparations for war made it more indispensable than ever. Thus, the Jewish elite reached the apex of its political influence during the final decade of the Dualist era.

Alongside its increasing political weight, the social prestige of the Jewish upper class was also slowly on the rise. In the eyes of contemporaries, "financial aristocracy" was not an empty expression. At the dawn of the First World War, the man in 
the street did not see much difference between the traditional aristocracy and the Jewish barons; he equally admired - or loathed - both of them.

\section{The National Office of Israelites and the Jewish community of Pest}

Since the National Office of Israelites (hereafter, Neolog Office), which was in charge of representing Neolog Jewry's "denominational" interests, was in the exclusive hands of the Jewish upper class, its activities must be taken into consideration here. The behaviour of the Neolog Office at the time of the Tiszaeszlár blood libel affair provides a precise summary of how it conceived Jewish interest representation. It did no more than ask the politician and lawyer Károly Eötvös to represent the Jewish defendants in the case. ${ }^{50}$ Beyond this, it did not move publicly against the rising antiSemitic tide and made active efforts to dissuade other Jews from doing so. After the outbreak of the blood libel in the spring of 1882, the Neolog Office remained silent. Its first memorandum to the Neolog communities was not issued until July 1883. In fact, it was not anti-Semitism that triggered the sending of the memorandum, but the Jewish reaction to it, or more precisely the attempt by the Jewish weekly Egyenlöség ["Equality"] to set up, under the name National Hungarian-Jewish Association, a defence organisation against anti-Semitism. Sticking to the dogma of de-ethnicised Judaism and anxious not to expose itself to accusations of political particularism, the Neolog Office stated that religious communities were the only legitimate institutional framework for Hungarian Jewry. This excluded any organised representation of Jewish political interests, which the Office opposed out of fear that it might be perceived as if Jews "were uniting for secret purposes." The memorandum prescribed passivity as a guiding principle, calling upon the Jews to avoid "public discussion of the court's verdict," and to refrain from "airing complaints through the press."

From the 1890s to the outbreak of the First World War, the Neolog Office remained similarly cautious. In the early 1890 s the Office first opposed, then became a passive observer of the struggle of the younger Jewish generation for the "reception" law. Its activities remained limited to sending memoranda on religious or denominational affairs. Like the Orthodox Office, it petitioned the Ministry for Religious and Educational Affairs to have Jewish schoolchildren freed from the obligation of writing and drawing on Saturday. From the 1890s, it sent repeated requests to the government asking for a rise in the financial state support given to the Jewish denomination.

Beyond these strictly denominational affairs, the Neolog Office stood by its lowprofile policy. In the two decades before the War, it refrained from speaking out openly against the anti-Semitic Catholic People's Party, against the consumer cooperatives established by the agrarian movement, against state discrimination, or the growing influence of the strongly anti-Semitic Jesuit congregations in public education. It did, however, demand that the government reject approval for the statutes of the otherwise tiny Zionist organisation, which, as the Neolog Office stated in 1908, "aims in the end to eradicate the Hungarianness of Hungarian Jewry." 52

Besides the Neolog Office, the Jewish Community of Pest, which counted among its leaders the cream of the Jewish commercial and industrial elite, was the only Jewish body influential enough to act in the name and interest of Neolog Jewry. It did take such action on several occasions prior to the granting of civil equality to the Jews, although it had no legal authority to do so either then or after 1867. After emancipation, however, it used precisely this fact as a justification for remaining in isolation, repeatedly stressing that it could have no other function than to perform the ritual tasks 
of the religious community. At its annual assembly, the succeeding presidents of the Jewish Community of Pest would declare that they were considering with "sympathy" movements that aimed to improve the situation of the Jews, but that the Jewish Community of Pest, by its nature, could not take part in them. ${ }^{53}$ At the time of the Tiszaeszlár blood libel affair, the Jewish Community of Pest reacted only once, when the Catholic priest Ignác Zimándy set out in a parliamentary speech to "prove" that the Jewish religion commanded the ritual use of Christian blood. The rabbinate of the Jewish Community of Pest and the Rabbinical Seminary issued a joint declaration pointing out that the alleged quotations of the Talmud were falsifications taken from the writings of August Rohling. ${ }^{54}$ Its stance regarding the movement for the "reception" of the Jewish denomination was similar to that taken by the Neolog Office; first opposition, then passivity.

The reluctance of the Neolog Office and the Jewish Community of Pest to react publicly on behalf of Jewish interests clearly stemmed from the fact that the main interest of the Jewish upper class which dominated these organisations - a good relation with the traditional political elite - commended them not to do so.

This should not obscure the fact that, at another level, the Neolog Office was quite active. Every month it received hundreds of requests sent by small Jewish communities, charitable organisations, rabbis or individual Jews. Regarding these countless smaller matters, insignificant at the national level, but certainly important for those concerned, the Neolog Office did what it could to help those who turned to it, either by intervening with the administration on their behalf, or by providing them with legal advice or even financial aid.

\section{The Jewish middle class}

Compared to the Jewish upper class, middle-class Jews were more sensitive to the heated nationalism of the Party of Independence. Nevertheless, there is no doubt that the majority of them also voted for the Liberal party. Such support is indirectly corroborated by the fact that in the four districts of Budapest with the highest percentage of Jewish population, eight of the 11 candidates elected in the course of the last six general elections of the Dualist era belonged to the Liberal Party, as against two MPs of the Party of Independence.

Nonetheless, middle-class Jewish support of the Liberal Party was not unconditional. An ambiguous allusion to Tiszaeszlár by a canvasser of the Liberal party candidate in the by-elections of Tapolca in 1895 was enough for the Jews of this small town, who otherwise voted for the Liberal Party, to cast their ballot in favour of the candidate of the Party of Independence. ${ }^{55}$ This sensitivity did not mean that the Jewish origin of a candidate belonging to the Party of Independence was enough in itself to divert middle-class Jewish support away from the Liberal Party. Among the Jewish MPs elected to the Parliament in 1881, the journalist Erno" Mezei, member of the Party of Independence, was without any doubt the one who fought with greater ardour and courage against rising political anti-Semitism; and yet, according at least to Egyenlöség, it was precisely the lack of support of the Jewish constituency that prevented him from being re-elected in $1884 .{ }^{56}$ Another member of the Party of Independence, the Jewish lawyer Soma Visontai, who also did not hesitate to speak up in defence of the Jews, failed to be elected in his hometown in the by- and general elections of 1887 , even though the Jewish vote could have made the difference. $^{57}$ 
At the time of the Tiszaeszlár blood libel affair, the Jewish middle class overwhelmingly adopted a strategy of wait and see. To set up an explicitly Jewish organisation with the aim of fighting anti-Semitism would also have entailed going against state power, which reacted belatedly to the violent manifestations against the Jews. Clearly, the Jewish middle class was not ready to depart from its loyalty to the governing Liberal party. Moreover, it was the authorities who finally took firm measures to defend the Jews against a segment of Hungarian society. This was the lesson of Tiszaeszlár. "Even today," wrote a Jewish pamphleteer, "only the bayonet and the rifle can protect the Jew against the ferocious excesses of society.", 58

The Jewish middle class acted more vigorously against the agrarian anti-Semitism that emerged in the mid-1890s. In the meantime, it had grown in social significance and self-assurance. It reacted by establishing, in 1904, the National Hungarian Commercial Association, charged with protecting the rights of merchants and traders. ${ }^{59}$ Like the National Association of Hungarian Industrialists, this body was not a Jewish pressure group, but most of its directors and members were Jewish. At any rate, agrarians regarded it as a Jewish front-organisation. In 1901, the future chairman of the Commercial Association, Pál Sándor, was elected Member of Parliament. In his policy speech, he summarised his social creed as follows:

I am a merchant; the member of a social class which is the principal factor in the expansion of the national economy. I am proud to be a member of this class. I am a merchant, and the more this class is subjected to unjust attacks and hostility, the more self-assuredly I shall stress my being a merchant. ${ }^{60}$

Clearly, being a merchant was here partly synonymous with being Jewish. It was meant to be - and was - understood this way.

Compared with upper-class Jews, middle-class Jews were more sympathetic to progressive ideas. The National Hungarian Commercial Association supported universal suffrage, as did the liberal press, whose journalists were in the majority Jews, and the Masonic lodges, whose members were also predominantly Jewish. ${ }^{61}$ Since we can arguably assume that their positions reflected the political orientation of the large majority of middle-class Jews, it seems that in the last decade of the Dualist era they stood halfway between the "realpolitical" conservatism of the Jewish upper class and the progressivism of the tiny bourgeois radical camp. Yet, the influence of the Jewish middle class on general political developments was more limited. With greater frustration, they ultimately stayed with the National Labour Party, the successor of the Liberal Party, or more precisely with István Tisza, who dominated the party from the turn of the century. In line with the adage "my enemies" enemy is my friend," the majority of middle-class Jews kept on supporting Tisza, who remained fundamentally liberal, consistently condemned anti-Semitism and put no obstacles before their economic activities.

During the Horthy era, middle-class Jews recalled the Dualist era as the golden age of liberalism. Irrefutably, their position was incomparably more favourable before 1914 than in the interwar period. Nevertheless, even during the Dualist era, the Jewish middle class could have reason to be anxious. With the access to parliamentary representation of the Catholic People's Party in 1896, there was once again a political formation, which, although its official programme did not explicitly mention the Jews, was clearly anti-Semitic. ${ }^{62}$ Anti-Semitism spread among the Christian middle classes. As far as the state apparatus was concerned, while anti-Jewish discrimination declined at the highest levels in the 1910s, this was not true in the middle levels of bureaucracy, 
where it remained constant, or maybe even got worse. ${ }^{63}$ At the same time, Jews were aware that active political anti-Semitism did not pose any real serious threat, or more precisely that the existing framework set clear limits to its potential advance. From the late $1890 \mathrm{~s}$, this idea was expressed repeatedly and in the most explicit way by some of the most famous Jewish journalists of the time. ${ }^{64}$ All things considered, most middle-class Jews felt fundamentally secure and considered their situation to be satisfactory. To persuade themselves of this, all they had to do was look at the situation of Jews in Vienna or in Germany.

\section{The Jewish weekly Egyenlöség}

Among Neolog Jews, there was one group who advocated a different way of making politics, the already mentioned Egyenlöség. The most important Neolog Jewish magazine was founded in 1882, at the time of the Tiszaeszlár affair, with the explicit goal of fighting anti-Semitism. Throughout the period, combativeness was its main feature. Egyenlöség represented a minority within the Jewish bourgeoisie, but an important minority. It quickly moved ahead of all other Jewish publications, reaching a readership of about 20,000 in the 1900s. Editor-in-chief of the weekly from 1886 until his death in 1915, Miksa Szabolcsi was a well-known figure in Hungarian Jewish life.

The authors of Egyenlöség fought against all manifestations of anti-Semitism with the same zeal that they showed in their criticism of the sometimes hypocritical government policies and of Jews who failed - in their estimation - to defend Jewish interests sufficiently, that is, the Neolog Office, the Jewish Religious Community of Pest and the Jewish MPs.

From the outset and with increasing vehemence, Egyenlöség demanded that Jewish MPs fight for Jewish interests. ${ }^{65}$

The Jewish MP [wrote Egyenlöség in 1887] cannot consider himself to be the representative of the Jewish denomination, but nobody can reasonably deprive him of the right to raise his voice in the interest of his denomination, to respond to unjust attacks, and to try to promote Jewish interests too [emphasis added]. ${ }^{66}$

Egyenlöség repeatedly stated that Jewish MPs had not only a moral, but also a political obligation to defend Jewish interests: "The great majority of Jewish MPs," declared Egyenlöség in 1908, "were elected in constituencies where there are a large number of Jewish voters whose votes decide the elections ... They were elected partly because they were Jews and because Jewish voters believed that their Jewish MPs would defend their interests not only as Hungarian citizens, but also when they need to be protected as Jews." 67

"The participation of the Jews in Hungarian political life," wrote András Kovács, "was governed by the maxim: never appear as a Jew or represent particular Jewish interests." ${ }^{68}$ Although this was true in the case of most Jewish MPs, and the large majority of the Jewish bourgeoisie, it certainly did not apply to Egyenlöség. The most important periodical of Hungarian Jewry called increasingly for the open expression and defence of Jewish interests in political life. In the run-up to the 1892 elections, it ran a long campaign to persuade Jewish voters to back only those candidates who clearly supported the "reception" bill. ${ }^{69}$ It encouraged the Jewish bourgeoisie to openly express and defend its interests, or more precisely, it repeatedly admonished it for not doing so. As the well-known writer and journalist Tamás Kóbor wrote before the general elections of 1901: 
Even in the most liberal periods, they did not love us for our beautiful eyes, but because of the strength we represented. ... In a lot of constituencies, the outcome of the elections depends on the Jewish vote. Where do Jewish voters exercise this influence for their own interests? ... Alkotmány ["Constitution," a clerical newspaper] is right; the Hungarian press is in fact a Jewish press. Where are those lines in the articles of Jewish journalists, which serve their own interests? ... Money too is in the hands of Jews. Where is that money used in the interest of liberalism? ... Stand up for what you really believe, speak and act the same way in society as you do so when you are among yourselves, do not try to please and do not be afraid. ${ }^{70}$

In contrast to most upper and middle-class Jews, whose loyalty to the government it regularly condemned, Egyenlöség moved gradually to the left of political spectrum. From the outset, it had been quite hostile to the traditional elite. From the 1890s onwards, it consistently demanded the introduction of universal suffrage and became increasingly sympathetic to the aims of socialism.

Nevertheless, it never reached the point of openly expressing political support for the Social Democratic Party. The latter's anti-capitalism and strident atheism were clear obstacles to such a development; but they were not the main reason. Egyenlöség was idealistic, but not blindly so. Restricted suffrage kept the Social Democrats out of Parliament. Between an Independence Party that still harboured anti-Semitic tendencies despite becoming more progressive in the years prior to the First World War, and the National Labour Party, led by the more conservative, but also more philosemitic István Tisza, there could be no real doubt regarding the choice of the Jewish bourgeoisie. As Egyenlöség acknowledged in 1914: "People will go where they do not get hurt. Jews have a right to dwell in Tisza's camp anyway, but as things are, they may also have a reason to do so." 71

Yet, the authors of Egyenlöség differed from the major part of the Jewish bourgeoisie in the sense that the issue for them was not whether the overall situation of Jews was satisfactory but whether it was as one might expect it to be in a truly liberal society. From this point of view, continuing state discrimination and the growing antiSemitism of the Christian middle classes made Egyenlöség consider the evolution of Hungarian society with growing pessimism. ${ }^{72}$ It turned away from Tisza, but it could not propose any realistic political alternative. In fact, there wasn't any.

\section{Conclusion}

The pessimism of Egyenlöség was certainly not shared by the majority of Hungarian Jews. Looking back in 1914 to the almost half-century of the Dualist era, they could rightly consider that it corresponded for them to a period of unprecedented economic and social ascendance, and finally, growing political power. Considering its main objective, that is, the possibility of living according to its own version of the Jewish faith, Orthodox Jewry's policy was clearly successful. The political situation commanded the Jewish bourgeoisie to refrain from asserting specifically Jewish interests on the political scene, but since this situation also set clear limits to the potential advance of anti-Semitism, it allowed them to avoid doing so. The attempt in 1883 by Egyenlöség to set up a defence organisation against anti-Semitism did not fail because of the Neolog Office's opposition, but through lack of support by the Jewish middle classes. As time went by, and especially from the beginning of the 1900 s, members of the Jewish bourgeoisie fought more and more openly for their interests, not as Jews, but rather as - and alongside gentile - industrialists, businessmen or simply bourgeois liberals. 


\section{Notes on contributor}

Miklós Konrád is a research fellow at the Institute of History, Hungarian Academy of Sciences. He graduated at the Université Paris IV Sorbonne and his main research interests are the ideology and politics of assimilation in Hungary, anti-Semitism and the Jews of Budapest. His publications include : "Le mouvement d'embourgeoisement de la noblesse et les Juifs dans la Hongrie du XIXe siècle," Revue des Études Juives (Vol. 159, Janvier-Juin 2000); "La femme juive de Budapest comme allégorie. L'image de la femme juive dans la littérature hongroise du tournant du siècle dernier," Revue des Études Juives (vol. 161, Janvier-Juin 2002); “Jewish Perception of Antisemitism in Hungary before World War I," Jewish Studies at the Central European University. IV, 2003-2005 (Budapest, Central European University, 2006); "Music halls and Jewish Identities in Budapest at the Turn of the Century," in Jewish Space in Central and Eastern Europe: Day-to-Day History, ed. Jurgita Šiaučiūnaitè-Verbickiene and Larisa Lempertiene (Newcastle: Cambridge Scholars Publishing, 2007). He is currently working on a monograph on Jewish conversions in Hungary in the nineteenth century.

\section{Notes}

1. Silber, Jews in the Hungarian Economy 1760-1945.

2. Hanák, "Polgárosodás és asszimiláció Magyarországon a XIX. Században," 513-36; Zeke, "Az izraelita felekezet Magyarországon 1895 és 1918 között," 241

3. On political anti-Semitism in Hungary, see Kubinszky, Politikai antiszemitizmus Magyarországon 1875-1890; Fischer, Entwicklungsstufen des Antisemitismus in Ungarn.

4. One should stress that in the Hungarian political life of the Dualist era, instead of the liberal versus conservative confrontation, the major parliamentary parties, that is, the Liberal Party and the Party of Independence, were opposed on the so-called "constitutional question," that is the approval or rejection of the Austro-Hungarian Compromise. Otherwise, liberalism remained their official political credo during the whole period.

5. On Kálmán and István Tisza, see Szabolcsi, Két emberöltö. Az Egyenlöség évtizedei, 38, 47; Szentpéteri, Gróf Tisza István, 10-12; Vermes, István Tisza; Gyurgyák, A zsidókérdés Magyarországon, 277-82.

6. Stein, "Naplómból. Emlékezés Khuen-Héderváry grófra," 68.

7. "A sztropkói eset a miniszterelnök előtt," Egyenlöség, August 20, 1911, 2.

8. Mosse, The German-Jewish Economic Elite 1820-1935, 349. See also Pulzer, Jews and the German State.

9. Janos, The Politics of Backwardness in Hungary, 117.

10. There is no statistical data about the number of Jewish MPs. The anti-Semitic Klaus Schickert estimated that 70 Jews became MPs in Hungary between 1867 and 1918. Schickert, Die Judenfrage in Ungarn, 121. William McCagg put the number at 102 or 103; McCagg, Jewish Nobles and Geniuses in Modern Hungary, 129, 185. None of them gave any further precision. According to my own research, there were at least 108 Jews elected to the lower chamber of the Hungarian Parliament during the Dualist era. Sixty of them were unconverted at the time of their first election.

11. The unbaptised Vilmos Vázsonyi, leader of the Democratic Party and MP after 1901, became Minister of Justice in 1917.

12. Katz, A House Divided.

13. A number of Jewish communities that objected to the ideological and organisational separation of Hungarian Jewry, and were thus called "Status-Quo" communities, remained independent. They united into a nationwide structure only in 1928. There were 232 status quo communities in 1900, amounting to $10 \%$ of the country's Jewish communities.

14. For a brief overview of orthodox positions, see Katz, "The Identity of Post-emancipatory Hungarian Jewry", 13-31; Katzburg, "Assimilation in Hungary during the Nineteenth Century: Orthodox Positions," 49-55.

15. In the Neolog synagogues, the corresponding figures were quite different: $76 \%$ used Hungarian, 23\% German, and only 1\% Yiddish; A Magyar Kir. Vallás- és Közokt. Minister jelentése 1900. évi müködéséről, 147.

16. On Ultra-Orthodoxy, see Silber, "The Emergence of Ultra-Orthodoxy," 23-84.

17. Compared to its Neolog counterpart, the Orthodox Office kept its members under much stricter supervision. Though its statutes did not grant the Orthodox Office the right to do 
so, it reserved the right to revise the statutes of Orthodox communities and charitable organisations. The expanded Orthodox statutes of 1906 went even further, stating expressly that any new Orthodox community could be established only with prior permission of the Orthodox Office.

18. M. Szabolcsi, “Orthodox testvéreink épülésére,” Egyenlőség, January 16, 1891, 9-10; Egy országgyűlési képviselö, "Káros irányban,” Egyenlöség, August 14, 1891, 4; M. Szabolcsi, "Néhány szó a magam dolgában," Egyenlőség, June 24, 1892, 4.

19. McCagg, Jewish Nobles and Geniuses in Modern Hungary, 89.

20. Blau, Emlékkönyv ...; Carmilly-Weinberger, The Rabbinical Seminary of Budapest.

21. The first Orthodox periodical published in Hungarian, Magyar Zsidó ("Hungarian Jews," 1867-70) was followed by Zsidó Hiradó ("Jewish Herald," 1891-1906) and Magyar Zsidó ("Hungarian Jews," 1908-1913). Both were semi-official organs of the Orthodox Office.

22. Viador, "Talmud-thóra," Zsidó Híradó, November 10, 1892, 1; Viador, "Talmud-thora," Zsidó Hiradó, October 1904, 2-3.

23. Prepuk, "Ortodox és neológ zsidók fellépése a vasárnapi munkaszünet enyhítéséért," 239-51.

24. L. Gutman, “A nyolc órai záróra és az ortodoxok,” A Pénzvilág, June 7, 1913, 704-6.

25. See Magyarországi rendeletek tára. 1899, II, 1887-90; Magyarországi rendeletek tára. 1900, II, 671-2.

26. Viador, “Az elnökválasztás," Zsidó Hiradó, November 1904, 3; Hivatalos Közlöny, 12/26 (1904), 541; Hivatalos Közlöny, 13/23 (1905), 448.

27. Moskovits, Jewish Education in Hungary, 180.

28. Kmety, A magyar közigazgatási jog kézikönyve, 485-7; Képviselöházi Napló 1910-15, vol. VIII (Budapest, 1911), 130-1.

29. Katzburg, Fejezetek az újkori zsidó történelemböl Magyarországon, 132-3.

30. Viador, "Az állami szubvenció," Zsidó Híradó, April 5, 1894, 1-2; Viador, "Az államsegély,” Zsidó Híradó, February 7, 1895, 1; Lipsicz Lipót, “Körirat,” Zsidó Híradó, June-July 1904, 2.

31. Viador, "Reczepczió?," Zsidó Híradó, Janurary 14, 1892, 1-3; K. Reich, "A reczepczió mozgalomról," Zsidó Híradó, February 4, 1892, 3-5; B. Schreiber, "Testvéreink, Izrael fiai!," Zsidó Híradó, March 17, 1892, 1-3; Viador, “A kormány programmja," Zsidó Híradó, November 10, 1892, 1; M. Ehrentheil, Rezeption und Orthodoxie.

32. L. Hartstein, “A peripheriák zsarnokai,” Magyar Zsidó, August 27, 1909, 1-3.

33. Eisner, Az izraelita hitfelekezet és hitközségeket érintö törvények és rendeletek gyüjteménye, 9-12; A Magyar Kir. Vallás- és Közokt. Minister jelentése 1905. évi müködéséröl, 142. Moreover, the authorities repeatedly dismissed requests by the Neolog Jews to reconvene the Jewish congress, the aim of which would have been to unite Hungarian Jewry.

34. Képviselőházi Napló 1896-1901, vol. XIV (Budapest, 1898), 98.

35. Szabó, "A magyar társadalom politikai szerveződése a dualizmus korában," 205-6.

36. Képviselőházi Napló 1887-1892, vol. XXI (Budapest, 1891), 399.

37. Wahrmann Mór Pest-lipótvárosi képviselöjelölt beszéde a január 16-án, esti 7 órakor a redout teremben tartott választási értekezleten (Pest, 1869), 8-9.

38. Képviselöházi Napló 1875-1878, vol. III (Budapest, 1876), 238.

39. Zeller, A magyar egyházpolitika 1847-1894, II, 1142-1376; Welker, "Between Emancipation and Antisemitism," 239-69. The bill on Christian-Jewish intermarriage finally failed to pass. Marriage between Jews and Christians became possible only with the introduction in 1894-5 of civil marriage and the "reception" of the Jewish denomination.

40. Welker, "Between Emancipation and Antisemitism," 255. The Anti-Semitic Party was founded in 1883. According to its programme, the party aimed at fighting "Jewish influence" in Hungarian economical and cultural life. The Anti-Semitic Party won 16 seats in the Parliament in the 1884 general elections, and 11 seats in 1887 (out of 413). In the 1892 general election, there were still a few candidates elected on an anti-Semitic programme, but the Anti-Semitic Party had ceased to exist.

41. Typical of this rationale are the speeches of Ferenc Chorin in January 1883 and Gyula Rosenberg in March 1898. See Képviselöházi Napló 1881-1884, vol. IX (Budapest, 1883), 293; Képviselőházi Napló 1896-1901, vol. XIV (Budapest, 1898), 98.

42. Képviselőházi Napló 1896-1901, vol. XXV (Budapest, 1900), 431. 
43. While the historiography has never dealt in detail with the question of the Jewish vote, historians of the Dualist era unanimously agree on that point. See Horváth, Magyar századforduló, 113; Vermes, István Tisza.

44. "Kortörténeti jegyzetek. A mi zsidóink," Huszadik Század, November 1908, 402-3; Jászi, Miért léptem ki a "Világ” szerkesztőségéből?.

45. Szabó, "A magyar társadalom politikai szerveződése a dualizmus korában," 201, 213.

46. The Law of Incompatibility was certainly the agrarians' major political victory. It effectively excluded from the lower chamber of Parliament those engaged in large industry and thus infringed the interests of the Jewish economical elite.

47. Janos, The Politics of Backwardness in Hungary, 114.

48. Deak, The Economy and Polity in Early Twentieth Century Hungary; Deak, "The Search for an Urban Alliance: The Politics of the National Association of Hungarian Industrialists [GyOSz] before the First World War," in Silber, Jews in the Hungarian Economy, 210-24.

49. Szabó, "Középosztály és újkonzervatívizmus," 178.

50. Katzburg, Fejezetek az újkori zsidó történelemböl Magyarországon, 131-2.

51. Gy. Klein - F. Rosenthál, "Válasz," Egyenlőség, August 12, 1883, 5.

52. F. Mezey - M. Mezei, “Az izr. országos irodájának véleménye a »Magyarországi czionista szervezet« kérvénye tárgyában,” Magyar Zsidó Szemle 25 (1908): 218. The statutes of the Hungarian Zionist Association were officially recognised only in 1927.

53. M. Szabolcsi, “A pesti izraelita hitközség,” Egyenlőség, March 6, 1891, 1; Választási közgyűlés jegyzőkönyve, 1907; Elöljárósági ülések jegyzőkönyvei, 1912, Magyar Zsidó Múzeum és Levéltár, PIH-I-C-1, PIH -I-A-3; Szabolcsi, Két emberöltö, 138, 181.

54. Groszmann, "A Pesti Izr. Hitközség Története," 50; Patai, The Jews of Hungary, 357.

55. Krúdy, Kossuth fia, 217.

56. S. Feleki, "Zsidó magyar írók és tudósok. Mezei Ernő," Egyenlőség, November 7, 1890, 9.

57. "Visontai dr. Gyöngyösön," Egyenlöség, February 13, 1887, 5-6; Visontai finally entered the Parliament in 1892.

58. Füredi, $A$ zsidó, 53.

59. Szende, A magyar közgazdaság és az Országos Magyar Kereskedelmi Egyesülés tevékenysége.

60. Sándor, Programmbeszéde, 4-5.

61. Horváth, Magyar századforduló, 384; Barcsay, A szabadkömüvesség bünei I, 110-11.

62. Szabó, "A Néppárt megalakulása," 169-208. The Catholic People's Party was founded in 1895 in reaction to the legislation on church policy. The party's programme called for the defence of Hungary's "Christian character," the protection of agriculture, a restriction of financial speculation, and a tax on stock exchange transactions. From 1896 to the collapse of the Austro-Hungarian Monarchy, the People's Party gained parliamentary representation in the Parliament. At its peak, in 1906, the party won 33 seats.

63. Konrád, "Zsidók és kitért zsidók a dualizmus korában," 389-95.

64. See for instance, Ignotus, "Makai Emil," A Hét, January 10, 1897, 29; Ignotus, "Zsidó liberalizmus," Nyugat, May 1, 1910, 629; T. Kóbor, "Új nóta," Egyenlöség, June 9, 1901, 2.

65. I. Acsády, "Mezei Ernő interpellácziója," Egyenlőség, November 19, 1882, 3; H-i., "A zsidó felekezetű képviselők," Egyenlőség, December 28, 1884, 6; A. Sturm, "A zsidók és a költségvetési vita," Egyenlöség, January 30, 1887, 1; K.S., "Hiába bujkálnak," Egyenlöség, March 14, 1909, 7-8.

66. “Zsidó képviselőinkről," Egyenlöség, September 25, 1887, 1.

67. “Zsidó képviselők," Egyenlöség, November 29, 1908, 5-6.

68. Kovács, "Jews and Politics in Hungary," 50.

69. V. Vázsonyi, "Szapáry Gyula gróf és a zsidók," Egyenlőség, August 21, 1891, 3; V. Vázsonyi, “A választások elött," Egyenlöség, January 15, 1892, 2-4; "Képviselőjelöltek nyilatkozatai," Egyenlöség, January 22, 1892, 4-6.

70. T. Kóbor, "Politika," Egyenlöség, July 7, 1901, 1-2.

71. "Glosszák a hétről," Egyenlöség, May 31, 1914, 4.

72. Konrád, "Jewish Perception of Antisemitism in Hungary before World War I," 177-90.

\section{Bibliography}

A Magyar Kir. Vallás-és Közokt. Minister jelentése 1900. évi müködéséröl [Report of the Hungarian Royal Ministry for Religious and Educational Affairs for the year 1900]. Budapest, 1901. 
A Magyar Kir. Vallás- és Közokt. Minister jelentése 1905. évi müködéséröl [Report of the Ministry for Religious and Educational Affairs for the year 1905]. Budapest, 1906.

Barcsay, A. A szabadkömüvesség bünei I [The Crimes of the Freemasons I]. Budapest: Egyesült Keresztény Nemzeti Liga, 1921.

Blau, L., M. Klein, S. Hevesi, and D. Friedmann. Emlékkönyv a Ferenc József Orsz. Rabbiképzö Intézet ötven éves jubileumára 1877-1927 [Memorial Volume for the $50^{\text {th }}$ Anniversary of the Francis Joseph National Rabbinical Seminary] I-II. Budapest: Publisher unknown, 1927.

Carmilly-Weinberger, M., ed. The Rabbinical Seminary of Budapest, 1877-1977. A Centennial Volume. New York: Sepher-Hermon Press, 1986.

Deak, G. The Economy and Polity in Early Twentieth Century Hungary. The Role of the National Association of Industrialists. Boulder, Colorado: East European Monographs, 1990.

Ehrentheil, M. Rezeption und Orthodoxie. Budapest: M. Burian, 1892.

Eisner, J. Az izraelita hitfelekezetet és hitközségeket érintő törvények és rendeletek gyüjteménye [Collection of Laws and Decrees concerning the Israelite Denomination and Communities]. Karcag: Kertész József Könyvnyomdája, 1925.

Fischer, R. Entwicklungsstufen des Antisemitismus in Ungarn, 1867-1939. Die Zerstörung der magyarisch-jüdischen Symbiose. München: R. Oldenbourg, 1988.

Füredi, B. A zsidó [The Jew]. Szombathely, 1882.

Groszmann, Zs. "A Pesti Izr. Hitközség Története" [The History of the Israelite Community of Pest]. In A Pesti Izraelita Hitközség fennállása 125-dik évfordulójának és a magyar izraeliták vallási receptiója 30-dik évfordulójának megünneplése [Celebration of the $125^{\text {th }}$ Anniversary of the Israelite Community of Pest and the $30^{\text {th }}$ Anniversary of the Reception of Hungarian Israelites], 39-54. Budapest: Pesti Izr. Hitközség, 1925.

Gyurgyák, J. A zsidókérdés Magyarországon. Politikai eszmetörténet [The Jewish Question in Hungary. A Political History of Ideas]. Budapest: Osiris, 2001.

Hanák, P. "Polgárosodás és asszimiláció Magyarországon a XIX. században” [Embourgeoisement and Assimilation in Hungary in the Nineteenth Century]. Történelmi Szemle 17, no. 4 (1974): 513-36.

Horváth, Z. Magyar századforduló. A második reformnemzedék története (1896-1914) [The Hungarian Turn of the Century. The History of the Second Generation of Reformers]. Budapest: Gondolat, 1961.

Janos, A.C. The Politics of Backwardness in Hungary, 1825-1945. Princeton, NJ: Princeton University Press, 1982.

Jászi, O. Miért léptem ki a "Világ" szerkesztöségéböl? [Why did I leave the editorial staff of the "Világ"?]. Budapest: Világosság Ny., 1911.

Katz, J. A House Divided: Orthodoxy and Schism in Nineteenth-Century Central European Jewry. Hanover, NH/London: University Press of New England, 1998.

- "The Identity of Post-emancipatory Hungarian Jewry." In A Social and Economic History of Central European Jewry, ed. Y. Don and V. Karady, 13-31. New Brunswick/ London: Transaction Publishers, 1990.

Katzburg, N. "Assimilation in Hungary During the Nineteenth Century: Orthodox Positions." In Jewish Assimilation in Modern Times, ed. B. Vago, 49-55. Boulder, Colorado: Westview Press, 1981.

—. Fejezetek az újkori zsidó történelemböl Magyarországon [Chapters in the Modern History of the Jews in Hungary]. Budapest: Osiris, 1999.

Képviselőházi Napló 1910-15 [Records of the Lower Chamber of the Parliament]. Budapest, 1867-1914.

Kmety, K. A magyar közigazgatási jog kézikönyve [Manual of Hungarian Administrative Law]. Budapest, 1897.

Konrád, M. "Jewish Perception of Antisemitism in Hungary before World War I." In Jewish Studies at the Central European University. IV. 2003-2005, ed. A. Kovács and M.L. Miller, 177-90. Budapest: Central European University, 2006.

. "Zsidók és kitért zsidók a dualizmus korában. A kitérés okai zsidó szemmel" [Jews and Converted Jews in the Dualist Era. The Motives of Conversion as seen by Jews]. Történelmi Szemle 49, no. 3 (2007): 373-402. 
Kovács, A. "Jews and Politics in Hungary." In Values, Interests and Identity: Jews and Politics in a Changing World, ed. P.Y. Medding, 50-63. New York/Oxford: Oxford University Press, 1995.

Krúdy, Gy. Kossuth fia [Kossuth’s Son]. Budapest: Magvetö, 1976.

Kubinszky, J. Politikai antiszemitizmus Magyarországon 1875-1890 [Political Antisemitism in Hungary 1875-1890]. Budapest: Kossuth, 1976.

Magyarországi rendeletek tára. 1899 [Collection of Hungarian Decrees for the year 1899] I-II. Budapest: 1899.

Magyarországi rendeletek tára. 1900 [Collection of Hungarian Decrees for the year 1900] I-II. Budapest, 1900.

McCagg, W.O. Jr. Jewish Nobles and Geniuses in Modern Hungary. Boulder, Colorado: East European Quarterly, 1972.

Moskovits, A. Jewish Education in Hungary (1848-1948). New York: Bloch Publishing Company, 1964.

Mosse, W.E. The German-Jewish Economic Élite, 1820-1935. A Socio-cultural Profile. Oxford: Clarendon Press, 1989.

Patai, R. The Jews of Hungary: History, Culture, Psychology. Detroit: Wayne State University Press, 1996.

Prepuk, A. "Ortodox és neológ zsidók fellépése a vasárnapi munkaszünet enyhítéséért" [The Action of Neolog and Orthodox Jews for the Easing of the Sunday Rest Law]. In A felhalmozás míve. Történeti tanulmányok Kövér György tiszteletére [The Work of Accumulation. Historical Studies Dedicated to György Kövér], ed. K. Halmos, J. Klement, Á. Pogány, and B. Tomka, 239-51. Budapest: Századvég, 2009.

Pulzer, P. Jews and the German State. The Political History of a Minority, 1848-1933. Oxford: Blackwell, 1992.

Sándor, P. Programmbeszéde. Elmondotta 1901. évi szeptember hó 24-én [Programme Speech. Delivered on 24 September 1901]. Budapest, 1901.

Schickert, K. Die Judenfrage in Ungarn. Jüdische Assimilation und antisemitische Bewegung im 19. und 20. Jahrhundert. Essen: Essener Verlagsanstalt, 1943.

Silber, M.K., ed. Jews in the Hungarian Economy 1760-1945. Studies Dedicated to Moshe Carmilly-Weinberger on his Eightieth Birthday. Jerusalem: The Magnes Press/The Hebrew University, 1992.

- "The Emergence of Ultra-Orthodoxy: The Invention of a Tradition." In The Uses of Tradition. Jewish Continuity in the Modern Era, ed. J. Wertheimer, 23-84. New York/ Jerusalem: The Jewish Theological Seminary of America, 1992.

Stein, A. "Naplómból. Emlékezés Khuen-Héderváry grófra" [From My Diaries. Recollections of Count Khuen-Héderváry]. In Szombat-Almanach az 5688. évre. (1927/28) [Sabbath Year Book for the Year 5688]. Budapest: Somré sabosz bizottság, 1927.

Szabó, D. "A magyar társadalom politikai szerveződése a dualizmus korában" [The Political Organization of the Hungarian Society in the Age of Dualism]. Történelmi Szemle 34, nos 3-4 (1992): 199-230.

"A Néppárt megalakulása" [The Birth of the People's Party]. Történelmi Szemle 20, no. 2 (1977): 169-208.

Szabó, M. "Középosztály és újkonzervativizmus" [Neo-Conservatism and the Middle Classes]. In Politikai kultúra Magyarországon 1896-1986 [Political Culture in Hungary 1896-1986], 177-90. Budapest: Medvetánc, 1989.

Szabolcsi, L. Két emberöltő. Az Egyenlőség évtizedei, 1881-1931 [Two Generations. The Decades of Egyenlőség, 1881-1931]. Budapest: MTA Judaisztikai Kutatócsoport, 1993.

Szende, P., ed. A magyar közgazdaság és az Országos Magyar Kereskedelmi Egyesülés tevékenysége 1904-1914 [The Hungarian Economy and the Activities of the National Hungarian Commercial Association 1904-1914]. Budapest: OMKE, 1914.

Szentpéteri, Kun B. Gróf Tisza István [Count István Tisza]. Debrecen, 1920.

Vermes, G. István Tisza: The Liberal Vision and Conservative Statecraft of a Magyar Nationalist. Boulder, Colorado: East European Monographs, 1985.

Welker, Á. "Between Emancipation and Antisemitism: Jewish Presence in Parliamentary Politics in Hungary 1867-1884." In Jewish Studies at the Central European University. II. 1999-2001, ed. A. Kovács and E. Andor, 239-69. Budapest: Central European University, 2002. 
Zeke, Gy. “Az izraelita felekezet Magyarországon 1895 és 1918 között” [The Israelite Denomination in Hungary Between 1895 and 1918]. In Az Országos Rabbiképzó Intézet Évkönyve, 1992-1995 [Year Book of the National Rabbinical Seminary 1992-1995], 241-61. Budapest: Országos Rabbiképző Intézet, 1995

Zeller Á. A magyar egyházpolitika 1847-1894 [The Hungarian Ecclesiastical Policy 1847-1894]. I-II. Budapest: Boruth E., 1894. 